\title{
Koronavirus SARS-CoV-2 v povrchových a odpadních vodách
}

\section{HANA MLEJNKOVÁ, VĚRA OČENÁŠKOVÁ, KATEŘINA SOVOVÁ, PETRA VAŠíČKOVÁ, EVA JURANOVÁ}

\author{
Klíčová slova: COVID 19 - SARS-CoV-2 - odpadní voda - povrchová voda - kontaminace - \\ epidemiologický přístup k odpadním vodám - nástroj včasného varování - biomarker
}

\section{SOUHRN}

Příspěvek přináší aktuální prehledné informace o virech a koronavirech včetně SARS-CoV-2, možnostech kontaminace povrchových a odpadních vod tímto virem, způsobu jeho stanovení ve vodách metodou RT-qPCR a využití monitoringu prítomnosti viru v odpadních vodách jako biomarkeru pro sledování jeho výskytu v populaci a jako nástroje včasného varování před prípadným nástupem nové viny choroby.

\section{ÚVOD}

Od počátku roku 2020 je slovo koronavirus jedním z nejčastěji užívaných slov ve světě. Př́činou je jeden ze zástupců této skupiny virů, SARS-CoV-2, původce respiračního onemocnění COVID-19, které ve velmi krátké době dosáhlo pandemických rozměrů. Tento př́spěvek přináší stručnou informaci o virových agens se zaměřením na koronaviry a aktuálně dostupné informace o SARS-CoV-2, jeho možném výskytu v povrchových a odpadních vodách včetně možnosti využití monitoringu těchto druhů vod.

\section{NĚCO O VIRECH A KORONAVIRECH}

Viry jsou jedinečné organismy známé od konce 19. století. Od ostatních mikrobů se liší tím, že obsahují jen jediný typ nukleové kyseliny (RNA nebo DNA) a ke svému pomnožení plně využívají vnímavou hostitelskou buňku. Odolnost virů závisí na jejich stavbě a na charakteru prostředí, v němž se nachází. Koronaviry jsou vybavené lipidovým obalem s výběžky tvořenými glykoproteiny. Na rozdíl od virů, které nemají proteinové obaly, jsou citlivější k éteru, desinfekčním prostředkům i k detergentům.

Koronaviry, jejichž název byl odvozen od tvaru podobného koruně (latinsky corona), jsou známé jako původci infekcí zviřrat (ptáků a savců) od 30. let 20. století, kdy byly prokázány jako původci akutního respiračního onemocnění kuřat. Genom koronavirů je zakódován v jednořetězcové RNA s pozitivní polaritou dosahující velikosti 30000 bází, což je nejvíce mezi známými RNA viry s nesegmentovaným genomem. Od 60. let 20. století jsou tyto viry známy i u člověka jako původci infekcí dýchacího ústrojí a pravděpodobně i trávicího traktu, u zvírat způsobují systémová onemocnění, včetně střevních. Přenos infekce je primárně vzdušnou cestou, tj. inhalací kapének nebo aerosolů, které vznikají při kašli a kýchání infikovaných osob, a rovněž kontaminovanými předměty. Nalezeny byly také ve stolici [1, 2].
V roce 2002 byl v Číně identifikován koronavirus SARS-CoV, který způsoboval těžký akutní respirační syndrom (SARS = Severe Acute Respiratory Syndrome). Virus byl identifikován až po několika měsících, čímž došlo k jeho rozšírení do 29 zemí světa na všech kontinentech. Během dvou let se nakazilo 8000 lidí a téměř 10 \% z nich zemřelo. Již několik let se žádný nový př́pad nevyskytl, proto nebyla ani odzkoušena vyvinutá vakcína. Předpokládá se, že virus přešel na člověka z netopýra a aktivním mezihostitelem byli drobní savci, např. cibetky [3-5]. U tohoto viru byla zkoumána distribuce $v$ těle zemřelých a byl nalezen v mnoha orgánech, včetně střevního traktu, což potvrdilo předpoklad, že může být vylučován i močí, výkaly nebo potem [6].

Další zoonózou koronavirového původu, která po přenosu na člověka způsobila akutní respirační onemocnění MERS (tj. Middle East Respiratory Syndrome), způsobil virus MERS-CoV, zjištěný v roce 2012 u osob, které přicestovaly z Arabského poloostrova. Nákaza proběhla ve dvou vlnách v letech 2012 a 2014 a postihla 1250 lidí, z nichž jí podlehlo přes 450 osob (36 \%). Nemoc se znovu objevila na konci roku 2019 v Saúdské Arábii (z 19 nakažených zemřelo do konce ledna 2020 v souvislosti s nemocí 8 pacientů). Pravděpodobným zdrojem byli infikovaní velbloudi [7].

Nový virus SARS-CoV-2 se rozšíril z Číny na konci roku 2019 postupně do více než 200 zemí. Ke dni 24. 4. 2020 byl prokázán u 2,48 milionu lidí, z toho u cca 170000 zemřelých (6,87 \%) [8], v ČR u 7 188, z toho 213 zemřelých (2,9\%). Při přenosu tohoto koronaviru z původního hostitele, kterým byli patrně netopýrii, hrál roli některý mezihostitel, pravděpodobně drobní savci luskouni [9]. Virus se extrémně rychle šírí díky jeho pozdním symptomatickým projevům a schopnosti přeživat na površích [10].

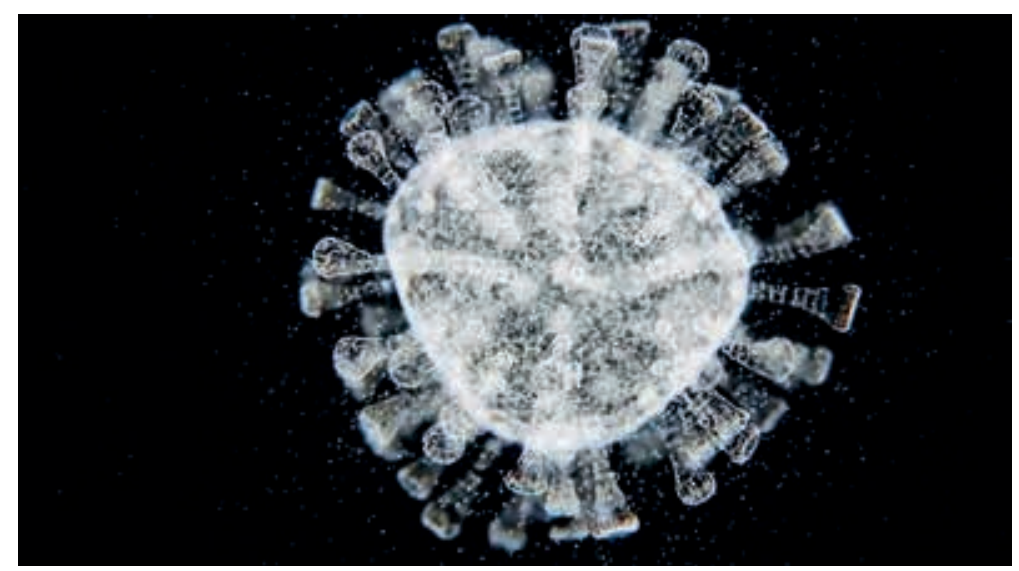

Obr. 1. Mikroskopický snímek koronaviru SARS-CoV-2

Fig. 1. Microscopic picture of coronavirus SARS-CoV-2 


\section{KONTAMINACE VOD}

Koronaviry jsou přednostně vylučovány respiračními sekrety, genové segmenty však byly prokázány také ve stolici infikovaných osob [11-17]. Vylučováni viru stolicí bylo zjištěno u cca 50 \% nakažených, průkaz životaschopných virionů ze střevního traktu však není jednoznačný $[18,19]$. Genové segmenty SARS-Cov-2 byly detekovány i ve stolici osob, včetně dětí, vykazujících pouze mírné nebo žádné př́iznaky onemocnění, a to i dlouho po jejich odeznění a negativním vyšetření respiračních sekretů [20, 21]. Kontaminace odpadních vod je tedy možná respiračními sekrety a fekáliemi, případně močí (nebylo jednoznačně prokázáno) infikovaných osob nebo jimi kontaminovanými předměty (vlhčené ubrousky, pleny apod.). Jediným zdrojem kontaminace vodního prostředí virem SARS-CoV-2 mohou tedy být odpadní vody a následně vody povrchové.

\section{RIZIKA ODPADNÍCH A POVRCHOVÝCH VOD}

Prvotní výzkumy prítomnosti viru SARS-CoV-2 v odpadních vodách byly aktuálně provedeny v Nizozemí. Metodou RT-qPCR (polymerázová řetězová reakce $\checkmark$ reálném čase s reverzní transkripcí) byly nalezeny specifické genové sekvence RNA, které prokázaly prítomnost genomu viru SARS-CoV-2 v odpadních vodách před úpravou na ČOV, dokonce již před prvním prokázaným klinickým průkazem u pacientů. Použitou metodou však nelze určit životaschopnost a virulenci viru ve vodním prostředí [22, 23]. Vzhledem k malé stabilitě koronavirů, pravděpodobné deaktivaci technologickými procesy čištění vod, nepř́iznivými fyzikálně-chemickými podmínkami prostředí a dobou zdržení lze v čištěných komunálních odpadních vodách předpokládat prítomnost pouze virových částic $\vee$ neinfekčním stavu. Stanovení virů SARS-CoV-2 v upravených odpadních vodách však dosud nebyly provedeny.

Z pohledu rizikovosti odpadních vod je nutné si uvědomit, že se v nich mohou vyskytovat vodou mnohem snadněji (fekálně orální cestou) prenosné patogenní mikroorganismy - noroviry, adenoviry, rotaviry, virus hepatitidy A a E, parazitičtí prvoci, patogenní bakterie, např. Campylobacter, Escherichia coli, včetně vysoce rizikových patogenů se získanou rezistencí na antibiotika aj. [24]. Od roku 2011 se v EU zdvojnásobil počet infekcí, které mají souvislost s kontaminovanou vodou. Jedná se zejména o viry se zvýšenou odolností ve vnějším prostředí (mezi něž však koronaviry nepatří) [25].

Virus SARS-CoV-2 je velmi citlivý k běžným antiseptickým prostředkům, proto při dodržování standardních postupů dezinfekce při styku s odpadními a recyklovanými vodami nelze predpokládat zvýšené riziko nákazy [26, 27].

Rizikem kontaminace povrchových vod a dalšího šíření infekčních agens ve vodním prostředí mohou být zejména nečištěné (malé komunální zdroje bez ČOV) a nedostatečně čištěné odpadní vody (menší obce bez dobře fungujících ČOV, technologické problémy na ČOV, mj. i vyvolané probíhající pandemií [28], deštové odlehčovače, poškozené kanalizační systémy a septiky. Přítomnost infekčních koronavirů v upravovaných pitných vodách je téměř vyloučena díky procesům úpravy a dezinfekce pitných vod z podzemních i povrchových zdrojů. Přeživání viru SARS-CoV-2 ve vodě a fekáliích nebylo dosud prokázáno, nicméně bylo zjištěno, že príbuzný virus SARS-CoV dokáže přežít v odpadních vodách, ve stolici a moči po dobu až 2 dnů při $20^{\circ} \mathrm{C}$ a při $4^{\circ} \mathrm{C}$ nejméně 14 dní [29].

Přítomnost viru ve vodách ovlivňuje množství dalších faktorů jako teplota, pH, chemické složení, doprovodná mikroflóra a další kontaminace vody, doba zdržení v kanalizační síti, technologické procesy čištění vod aj. Lze předpokládat, že běžné čistírenské technologie a doba zdržení v procesech čištění nový koronavirus inaktivují. Chování viru v čistírenských kalech nebylo zatím studováno nebo publikováno. Spolehlivou likvidaci málo odolných koronavirů i odolnějších infekčních agens by zajistil dezinfekční stupeň, zařazený jako konečný krok čištění odpadních vod. Tento stupeň však není v ČR do čistírenských procesů zařazen [30]. Legislativně je dezinfekční stupeň vyžadován od února 2020 pro odpadní vody ze zdravotnických zařizení [31]. Naopak u recyklovaných odpadních vod jak městských, tak šedých riziko přenosu infekčních mikroorganismů nehrozí, nebot dezinfekce je základní operací jejich úpravy [32].

Obecně je velmi důležité pohližet na odpadní vodu, zejména před vyčištěním, jako na vysoce rizikový materiál, a to z pohledu možného přenosu celé škály patogenních a podmíněně patogenních mikroorganismů, jejichž stanovení současná legislativa zatím nevyžaduje [33].

\section{STANOVENÍ SARS-COV-2 VE VODÁCH}

Detekce virů ve vzorcích prostředí (včetně vody) je odvozena od průkazu virových agens v klinických vzorcích. Postupy jsou většinou založeny na molekulárně-biologických metodách (tzn. na přimé detekci genomu viru). Přesto je průkaz virů ve vodě oproti klinickým vzorkům časově i metodicky náročnější záležitost. Koncentrace virových částic ve vzorcích vod je většinou velmi nízká (často i pod limitem detekce). Na rozdíl od bakterií nelze počet virových částic navýšit pomnožením pred vlastní analýzou vzorku. Proto jsou vhodné metody izolace a detekce virových částic jedním z klíčových faktorů pro úspěšný průkaz a stanovení rizik spojených s kontaminovanými matricemi.

Analýza vzorků vody se skládá z několika na sebe navazujících kroků. Jedním z hlavních a zároveň kritických bodů je zakoncentrování virů ze vzorku. K tomuto účelu Ize použít několika přístupů, které se liší účinností s ohledem na typ viru i druhy analyzovaného vzorku vody. Nejčastěji využivanými metodami pro zakoncentrování virových částic ze vzorků vod jsou techniky adsorpčně-eluční, v tomto prípadě se jedná o metody založené na pozitivně či negativně nabitých filtrech. Mezi další možné přístupy patři metody ultrafiltrace, ultracentrifugace, prímá flokulace, imunomagnetická separace nebo chromatografické techniky [34-36]. Jednotlivé metody Ize vzájemně kombinovat či provádět $v$ sérii. Nicméně každým dalším krokem $v$ rámci procesu analýzy vzorku dochází k významným ztrátám, a tak snížení citlivosti. Při volbě dané metody je třeba zvážit charakteristiku jak analyzovaného vzorku vody, tak virových agens, a následně provést optimalizaci metody pro její rutinní použití. Použitá metoda musí být dostatečně specifická, citlivá a standardizovaná.

$\checkmark$ prípadě metod průkazu virových částic ve vzorcích vody, které jsou založeny přímo na detekci genomu viru, je po zakoncentrování virových částic nutné provést extrakci nukleových kyselin (DNA, RNA). V rámci tohoto kroku analýzy vzorku jsou uvolněny nukleové kyseliny z virových obalů (proteinové a lipidové vrstvy) a poté jsou odstraněny nežádoucí zbytky a inhibiční faktory, které mohou interferovat $s$ následně prováděnými detekčními metodami. $K$ tomuto účelu jsou nejčastěji používány komerčně dostupné soupravy, jejichž výhodou je snadná reprodukovatelnost a relativně snadné provedení. Následujícím krokem analýzy vzorku je v současné době nejčastěji používaná PCR v reálném čase (qPCR), v prípadě RNA virů RT-qPCR (s reverzní transkripcí). Evropská komise zveřejnila standardizované laboratorní metody k průkazu a kvantifikaci pouze norovirů a viru hepatitidy $A, v$ prípadě vody se jedná o analytický postup pouze pro balenou pitnou vodu [37, 38]. Vhodnost zde uvedeného postupu pro analýzu ostatních druhů vod je diskutabilní. Nicméně v rámci ISO metod je dán systém kontrol jednotlivých kroků analýzy každého jednoho vzorku, což zajištujuje validní a porovnatelné výsledky.

I detekce SARS-CoV-2 je prováděna molekulárně-biologickými metodami (RT-qPCR), tj. ve vzorcích jsou hledány specifické úseky virové RNA. Metoda tedy neprokáže, zda je virus $v$ infekčním stavu. Nicméně stanovení virové RNA ve vodách je vhodné pro sledování tzv. biomarkerů epidemiologické situace výskytu nemoci COVID 19 v populaci. Není vhodné pro sledování možnosti šírení infekce vodním prostředím a přežívání viru ve vodách. Pro stanovení životaschopných virů jsou používány kultivační metody, které využívají jako hostitelské buňky tkáňové kultury [1]. Tyto metody jsou často náročné na provedení a vyžadují vysoce specializované vybavení laboratoří, k rutinním analýzám jsou tudíž nepoužitelné. 
Je nutno zmínit, že i s těmito vzorky je třeba zacházet, zejména při manipulaci s primárním vzorkem před jeho inaktivací, podle pravidel pro vzdušnou a kontaktní nákazu, tzn. použití biohazardního boxu třídy II, za použití dostatečných osobních ochranných pomůcek; ochrana dýchacích cest, obličeje (očí), rukou (tzv. lokální režim BSL-3). Při dalších manipulacích s již inaktivovaným materiálem dodržovat postupy odpovídající BSL-2 režimu. Při práci v laminárním boxu podle doporučení ECDC (European Centre for Disease Prevention and Control) nejsou vyžadovány respirátory FFP2 a FFP3 [39].
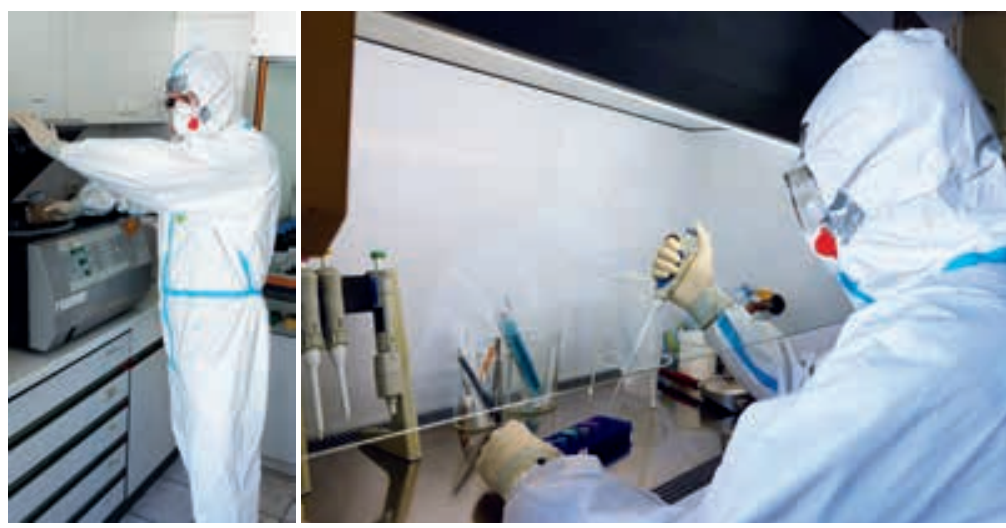

Obr. 2. Detekce SARS-CoV-2 v odpadních vodách (Maňásek, VúVeL, 2020)

Fig. 2. Detection of SARS-CoV-2 in wastewater (Maňásek, VúVeL, 2020)

\section{MONITORING ODPADNÍCH VOD JAKO NÁSTROJ VČASNÉHO VAROVÁNÍ}

Epidemiologický prístup k odpadním vodám (WBE - Wastewater Based Epidemiology) je interdisciplinární obor sdružující odborníky z příslušných vědních oblastí, kteří se zajímají o aplikaci a vývoj použivání kvantitativního měěení lidských biomarkerů v odpadních vodách za účelem hodnocení životního stylu, zdraví a expozice populace nejrůznějším látkám. Tento prístup je aktuálně využíván napríklad pro monitoring spotřeby nezákonných drog a dalších látek v populaci nejen ve Výzkumném ústavu vodohospodářském T. G. Masaryka, v. v. i., [40] ale i jinde ve světě [41].

Epidemiologický prístup nabízí využití také při predikci potenciálního šíření infekcí, a to detekcí výskytu infekčních agens v odpadních vodách. Vzhledem ke skutečnosti, že aktuálně se šírící virus SARS-CoV-2 je vylučován také stolicí infikovaných osob, je nasnadě, že se s největší pravděpodobností bude vyskytovat $\vee$ komunálních odpadních vodách. Tuto skutečnost potvrdil tým expertů z Výzkumného ústavu pro vodní hospodářství KWR v Nieweigenu (Nizozemí), který již 20. března 2020 publikoval článek, ve kterém jsou popsány výsledky experimentu zahájeného tři týdny před oficiálním zjištěním prvního pozitivního pacienta $v$ této zemi $[22,23]$. Je žrejmé, že s počtem infikovaných jedinců $\checkmark$ monitorované populaci narůstá i množství vyloučených virů do odpadní vody. Prostřednictvím jejich detekce $v$ odpadních vodách je možné poskytnout jedinečné epidemiologické informace o výskytu SARS-CoV-2 v populaci (př́tomnost, absence, trendy - nárůst, stagnace, úbytek) [42]. Při správně nastaveném systému monitoringu odpadních vod bude možné sledovat nástup a vývoj počtu virových onemocnění v dalších obdobích, nebo monitoring využít jako nástroj včasného varování pro nastavení systému účinného dohledu nad šiřením nákazy.

Problematikou SARS-CoV-2 v odpadních vodách se zabývá celosvětová platforma "Wastewater-Based Epidemiology for COVID-19" [43]. Monitoring odpadních vod se rozbíhá v Americe, Španělsku [44], Austrálii [45], Brazílii, Rakousku [46] a dalších zemích. Při testech v Massachusetts 25. března 2020 byly v odpadních vodách zjištěny významně vyšší titry virů, než se očekávalo na základě klinicky potvrzených prípadů [47].
Epidemiologická situace v ČR by mohla být úspěšně sledována s využitím monitoringu odpadních vod přiváděných na ČOV, kterých je u nás podle informací Ministerstva zemědělství 3166 (9 nad 100000 ekvivalentních obyvatel (EO), 122 nad 10000 EO, 417 nad 2000 EO a 2618 do 2000 EO). Ekvivalentní obyvatel je uměle zavedená jednotka používaná pro návrh potřebné kapacity čistíren odpadních vod pro konkrétní území. Ekvivalentní obyvatel představuje normovou produkci odpadní vody o objemu 150 I/den a produkci znečištění $60 \mathrm{~g} \mathrm{BSK} /$ den. Podle počtu napojených obyvatel na ČOV by monitoringem jejich odpadních vod mohl být podchycen stav u cca 80 \% obyvatel ČR, sledováním ČOV nad 10000 EO by bylo podchyceno více než 50 \% obyvatel ČR. Epidemiologické riziko by mohly představovat také volné výusti nečištěných odpadních vod do vod povrchových, kterých je u nás evidováno 4545 (to odpovídá cca 20 \% obyvatel ČR) [48].

Monitoring výskytu SARS-CoV-2 v odpadních vodách začal ve VúV TGM, v. v. i., v polovině dubna 2020, a to ve spolupráci s analytickou laboratoŕí Výzkumného ústavu veterinárního lékařství, v. v. i., v Brně (VúVeL), která se zabývá stanovením virů ve vodách, a provozovateli ČOV.

Aktuálně probíhá spolupráce s cca 20 ČOV, většina je o velikosti $10000-100000$ EO, ale jsou zařazeny i menší ČOV do 2000 a do 10000 EO a také jedna ČOV nad 100000 EO. Celkově je na tyto ČOV napojeno přes 760000 obyvatel (cca 912000 EO). V príslušných okresech bylo od začátku epidemie do 29. 4.2020 hlášeno cca 1280 nakažených osob, tj. 0,17\% napojených.

V první etapě monitoringu byly analyzovány vzorky z 20 lokalit, př́tomnost specifických genových segmentů viru SARS-CoV-2 byla zjištěna na 6 ČOV, tj. $30 \%$. Ve vzorcích byla molekulárně-biologickou metodou PCR detekována také přitomnost dalších hygienicky významných skupin virů (norovirů a adenovirů), které byly př́tomny i v čištěných odpadních vodách, což potvrzuje, že použitá metoda je dostatečně spolehlivá a citlivá.

Předběžné výsledky ukazují, že zvolený přístup cílený na průkaz výskytu viru SARS-CoV-2 v odpadních vodách je pro daný účel využitelný. Relativně nízký záchyt pozitivních nálezů ve sledovaných ČOV Ize vysvětlit malým podílem nakažených ve sledovaných oblastech. Dalšími faktory ovlivňujícími úspěšnost detekce virových segmentů nukleových kyselin ve vzorcích odpadních vod může být možnost projevu nemoci COVID-19 bez gastrointestinálních symptomů, které jsou podle dosavadních zahraničních výzkumů doprovázeny vylučováním virových částic stolicí pouze ve 2-50 \% případů, a pravděpodobný malý príspěvek virových částic od asymptomatických osob (nebylo dosud dostatečně studováno).

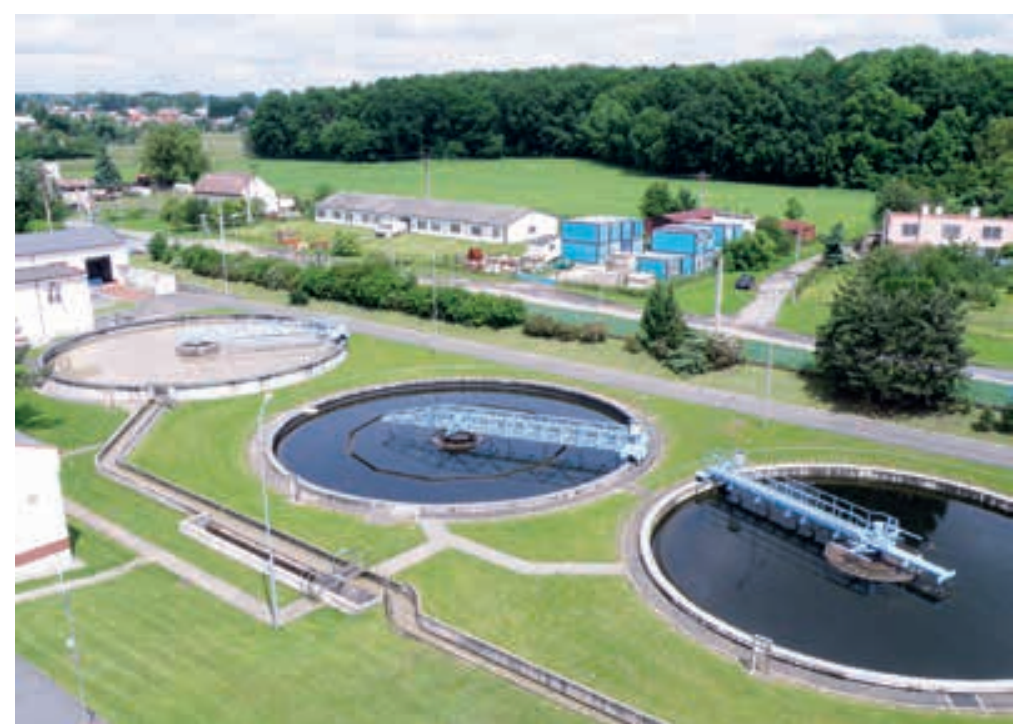

Obr. 3. Čistírna odpadních vod

Fig. 3. Wastewater treatment plant 
Výzkumný ústav vodohospodářský T. G. Masaryka, v. v. i., se aktuálně zapojuje do mezinárodní iniciativy zabývající se analýzou SARS-CoV-2 v odpadních vodách (SARS-CoV-2 in wastewater international collaborative study) pod záštitou asociace NORMAN, která sdružuje referenční laboratoře, výzkumná centra a organizace zabývající se monitoringem a biomonitoringem emergentních látek (nově vzniklých znečištujuících látek) v životním prostředí, a výzkumného týmu KWR Water Research Institute z Holandska. Jedním z cílů je vytvoriit jednotný postup pro odběr, uchovávání a analýzu vzorků pro stanovení SARS-CoV-2 v odpadních vodách.

Náš další výzkum bude zaměřen na optimalizaci jednotlivých kroků metodického postupu, na hledání spodní hranice použitelnosti metody pro účelový monitoring odpadních vod, zaměřený na stanovení infekčních agens v odpadních vodách a na návrh pro využití monitoringu jako systému včasného varování.

\section{ZÁVĚR}

Aktuální stav poznání potvrzuje možnost výskytu původce nemoci COVID-19 $\checkmark$ nečištěných odpadních vodách před úpravou na Čov, s největší pravděpodobností zde ale nepredstavuje pro nakládání s těmito vodami větší riziko než jiná infekční agens, která mohou být v odpadních vodách prítomná. Př práci s odpadními vodami je vždy nutné dodržování prísných hygienických opatření, která prítomná rizika eliminují [49-51].

Výskyt koronaviru SARS-CoV-2 v čištěných odpadních vodách nebyl dosud sledován. Lze předpokládat, že i zde se mohou vyskytovat fragmenty virových částic $v$ neinfekčním stavu. Tento předpoklad vychází z malé stability koronavirů, k jejichž deaktivaci zde přispívají technologické procesy čištění vod a nepř́iznivé fyzikálně-chemické podmínky prostředí pro jejich prežití. Skutečný stav pro virus SARS-CoV-2 je třeba potvrdit cíleným výzkumem.

Riziko infekce patogenními a podmíněně patogenními mikroorganismy mohou predstavovat volné výusti odpadních vod, které jsou vypouštěny do recipientů povrchových vod bez úpravy na komunálních ČOV.

Hygienicky významná kontaminace povrchových vod jako recipientů odpadních vod infekčním koronavirem SARS-CoV-2 je, i přes současný nedostatek konkrétních analytických dat, málo pravděpodobná.

Systematický monitoring komunálních odpadních vod může přinést důležité informace o výskytu viru ve sledované populaci. Předpokládá se možnost jeho využití jako nástroje včasného varování před případným nástupem další viny šírení choroby COVID-19 a poté jeho využití při sledování vývoje epidemie či účinnosti zavedených opatření.

Současná situace rychle se širíicí nákazy, vyvolané silně infekčním virem, poukázala na to, že výskytu hygienicky významných mikroorganismů ve vodním prostředí by bylo dobré věnovat zvýšenou pozornost nejen v případě současné pandemie.

\section{Poděkování}

Tento príspěvek a probíhající monitoring je finančně podpořen z Institucionálních prostředků na rozvoj výzkumné organizace Vúv TGM, v. v. i., v rámci interního grantu č. 3600.52.33/2020 a z projektu Čistá voda - zdravé město. Komunálni odpadní voda jako diagnostickémedium hlavního města Prahy financuje Hlavníměsto Praha v rámci Operačního programu Praha - pól růstu ČR, CZ.071.02/0.0/0.0/16_040/0000378.

\section{Literatura}

[1] GREENWOOD, D., SLACK, R.C.B., and PEUTHERER, J. Lékařská mikrobiologie, 1999, Avicenum, Grada, 686 s. [2] PŘECECCHTĚL, F. a kol. Lékařská mikrobiologie. Skriptum UJEP, Brno. SPN, Praha, 1988, 330 s. [3] CHAN, P.K. and CHAN, M.C. Tracing the SARS-coronavirus. J. Thorac. Dis., 2013, Vol. 5, No. 2, p. 118-121. DOl:10.3978/j.issn.2072-1439.2013.06.19. PMID 23977431.
[4] Ministerstvo zdravotnictví ČR. Výskyt nového koronaviru souvisejícím s těžkým respiračním onemocněním. Dostupné z: http://www.mzcr.cz/dokumenty/vyskyt-noveho-koronaviru-souvisejicim-s-tezkym-respiracnim-onemocnenim_6822_114_1.html

[5] Státní zdravotní ústav, Centrum epidemiologie a mikrobiologie: Koronaviry - přehled.

[6] DING, Y., HE, L., ZHANG, Q., et al. Organ distribution of severe acute respiratory syndrome (SARS) associated coronavirus (SARS-CoV) in SARS patients: implications for pathogenesis and virus transmission pathways. The Journal of Pathology, 2004, 203(2), p. 622-630. ISSN 0022-3417. DOI: 10.1002/ path.1560. Dostupné také z: http://doi.wiley.com/10.1002/path.1560

[7] WHO. Middle East respiratory syndrome coronavirus (MERS-CoV) - The Kingdom of Saudi Arabia. Dostupné z: https://www.who.int/csr/don/24-february-2020-mers-saudi-arabia/en/

[8] Bnonews. Tracking coronavirus: Map, data and timeline. Dostupné z: https://bnonews.com/ index.php/2020/04/the-latest-coronavirus-cases/

[9] CORMAN, V., BLEICKER, T., BRÜNINK, S., DROSTEN, CH., LANDT, O., KOOPMANS, M., ZAMBON, M., and PEIRIS, M. Diagnostic detection of Wuhan coronavirus 2019 by real-time RT-PCR. World Health Organisation [online], 2020-01-13 [cit. 2020-01-23]. Dostupné z: www.who.int.

[10] CHIN, A.W.H., CHU, J.T.S., M., et al. Stability of SARS-CoV-2 in different environmental conditions. The Lancet Microbe, 2020. ISSN 2666-5247. DOI: 10.1016/S2666-5247(20)30003-3. Dostupné z: https:// linkinghub.elsevier.com/retrieve/pii/\$2666524720300033

[11] WANG, W., XU, Y., GAO, R., LU, R., HAN, K., WU, G., and TAN, W. Detection of SARS-CoV-2 in Different Types of Clinical Specimens. JAMA. ISSN 0098-7484. DOI: 10.1001/jama.2020.3786. Dostupné z: https:// jamanetwork.com/journals/jama/fullarticle/2762997

[12] MIRI, S.M., ROOZBEH, F., RAD, A.O., ALAVIAN, S.M. Panic of Buying Toilet Papers: A Historical Memory or a Horrible Truth? Systematic Review of Gastrointestinal Manifestations of COVID-19. HEPATITIS MONTHLY. Volume: 20 Issue: 3, Article Number: e102729. Published: MAR 2020. DOI: 10.5812/ hepatmon.102729.

[13] ZHANG, T.Q., CUI, X.J., ZHAO, X., et al. Detectable SARS-CoV-2 viral RNA in feces of three children during recovery period of COVID-19 pneumonia. Journal of Medical Virology, Early Access: APR 2020. DOI: $10.1002 /$ jmv.25795

[14] LO, I.L., LIO, C.F., CHEONG, H.H., LEI, C.I., CHEONG, T.H., ZHONG, X., TIAN, YK. and SIN, N.N. Evaluation of SARS-COV-2 RNA shedding in clinical specimens and clinical characteristics of 10 patients with COVID-19 in Macau. International Journal Of Biological Sciences, 2020, Vol. 16, No. 10, p. 1698-1707. DOI: 10.7150/ijbs.45357

[15] TIAN, Y., RONG, L., NIAN, W.D., and HE, Y. Review article: gastrointestinal features in COVID-19 and the possibility of faecal transmission. Alimentary Pharmacology \& Therapeutics, 2020, Vol. 51, No. 9, p. 843-851. DOl: 10.1111/apt.15731.

[16] HINDSON, J. COVID-19: faecal-oral transmission? Nature Reviews Gastroenterology \& Hepatology. Early Access: MAR 2020. DOI: 10.1038/s41575-020-0295-7.

[17] YEO, CH., KAUSHAL, S., and YEO, D. Enteric involvement of coronaviruses: is faecal-oral transmission of SARS-CoV-2 possible? The Lancet Gastroenterology \& Hepatology, 2020, 5(4), p. 335-337. ISSN 24681253. DOI: 10.1016/S2468-1253(20)30048-0. Dostupné z: https://linkinghub.elsevier.com/retrieve/pii/ S2468125320300480

[18] XIAO, F., TANG, M., ZHENG, X., LIU, Y., LI, X. and SHAN, H. Evidence for Gastrointestinal Infection of SARS-CoV-2. Gastroenterology, 2020. ISSN 0016-5085. DOl: 10.1053/j.gastro.2020.02.055. Dostupné z: https://linkinghub.elsevier.com/retrieve/pii/S0016508520302821

[19] 'Sewage surveillance' may be early warning tool in fight against COVID-19, says one study interview with Medema. Dostupné z: https://www.pri.org/stories/2020-04-20/sewage-surveillance-may-be-early-warning-tool-fight-against-covid-19-says-one

[20] XU, Y., LI, X., ZHU, B., et al. Characteristics of pediatric SARS-CoV-2 infection and potential evidence for persistent fecal viral shedding. Nature Medicine, 2020, 26(4), p. 502-505. ISSN 1078-8956. DOI: 10.1038/s41591-020-0817-4. Dostupné z: http://www.nature.com/articles/s41591-020-0817-4

[21] CAO, Q., CHEN, Y.CH., CHEN, CH.L., and CHIU, CH.H. SARS-CoV-2 infection in children: Transmission dynamics and clinical characteristics. Journal of the Formosan Medical Association, 2020, 119(3), p. 670-673. ISSN 0929-6646. DOI: 10.1016/j.jfma.2020.02.009. Dostupné z: https:// linkinghub.elsevier.com/retrieve/pii/S092966462030067X

[22] MEDEMA, G. et al. Presence of SARS-Coronavirus-2 in sewage. 2020. DOI: https://doi. org/10.1101/2020.03.29.20045880

[23] What we learn about the Corona virus through waste water research. Dostupné z: www.kwrwater. $\mathrm{nl} / \mathrm{en} / \mathrm{actueel} /$ what-can-we-learn-about-the-corona-virus-through-waste-water-research/

[24] CACACE, D., FATTA-KASSINOS, D., MANAIA, C.M., CYTRYN, E., et al. Antibiotic resistance genes in treated wastewater and in the receiving water bodies: A pan-European survey of urban settings. Water Res., 2019, 162, Oct 01, p. 320-330.

[25] VAŠ́ČKOVÁ, P. a kol. Výskyt významných virů způsobujících alimentární infekce v povrchových i pitných vodách ČR. In: Sborník konference Vodárenská biologie 2020, Praha 5.-6. 2. 2020, s. 20-24.

[26] IWA: Covid-19: A Water Professional's Perspective - on-line webinar 8. 4. 2020.

[27] KAMPF, G., TODT, D., PFAENDER, S., and STEINMANN, E.. Persistence of coronaviruses on inanimate surfaces and their inactivation with biocidal agents. Journal of Hospital Infection, 2020, 104(3), p. 246-251. DOI: 10.1016/j.jhin.2020.01.022. ISSN 0195-6701. Dostupné z: https://linkinghub.elsevier.com/retrieve/ pii/S0195670120300463 
[28] Koronavirus útočí na kanalizační trubky. Zvýšená spotřeba zvlhčovacích ubrousků může ucpat čističky. Dostupné z: https://www.lidovky.cz/domov/koronavirus-utoci-na-kanalizacni-trubky-zvysenaspotreba-zvlhcovacich-ubrousku-muze-ucpat-cisticky.A200405_151301_In_domov_ele

[29] Water Services Association of Australia, COVID-19 Fact Sheet. (accessed March 04, 2020).

[30] European Environment Agency. Urban Waste Water Treatment Directive. Dostupné z: https:// www.eea.europa.eu/themes/water/european-waters/water-use-and-environmental-pressures/ uwwtd

[31] ČSN 75 6406. Nakládání s odpadními vodami ze zdravotnických zařizení vypouštěnými do stokové sítě pro veřejnou potřebu (únor 2020).

[32] Koronavirus ve vodách aneb hrozí nám „nákaza z vody”? Dostupné z: https://tvp.vscht.cz/home/ covid-19-ve-vodach

[33] MLEJNKOVÁ, H., SLEZÁKOVÁ, K. a PETRÁNOVÁ, A. Charakterizace fekální kontaminace a hygienických rizik spojených s vypouštěním odpadních vod z komunálních čistíren odpadních vod do toků. VTEl, 2011, roč. 53, č. 1, s. 16-18. ISSN 0322-8916.

[34] BRASSARD, J., SEYER, K., HOUDE, A., SIMARD, C., and TROTTIER, Y.L. Concentration and detection of hepatitis $A$ virus and rotavirus in spring water samples by reverse transcription-PCR. Journal of Virological Methods, 2005, 123(2), p. 163-169. DOI: 10.1016/j.jviromet.2004.09.018. ISSN 0166-0934. Dostupné z: https://linkinghub.elsevier.com/retrieve/pii/S0166093404002988

[35] CALGUA, B., MENGEWEIN, A., GRUNERT, A., et al. Development and application of a one-step low cost procedure to concentrate viruses from seawater samples. Journal of Virological Methods, 2008, 153(2), p. 79-83. DOI: 10.1016/j.jviromet.2008.08.003. ISSN 0166-0934. Dostupné z: https://linkinghub. elsevier.com/retrieve/pii/S0166093408003078

[36] CALGUA, B., RODRIGUEZ-MANZANO, J., HUNDESA, A., SUÑEN, E., CALVO, M., BOFILL-MAS, S., and GIRONES, R. New methods for the concentration of viruses from urban sewage using quantitative PCR. Journal of Virological Methods, 2013, 187(2), p. 215-221. DOI: 10.1016/j.jviromet.2012.10.012. ISSN 01660934. Dostupné z: https://linkinghub.elsevier.com/retrieve/pii/S0166093412003710

[37] ISO 15216-1:2017. Microbiology of the food chain - Horizontal method for determination of hepatitis A virus and norovirus using real-time RT-PCR — Part 1: Method for quantification. International Organization for Standardization, 2017.

[38] ISO 15216-2: 2019. Microbiology of the food chain - Horizontal method for determination of hepatitis A virus and norovirus using real-time RT-PCR — Part 2: Method for qualitative detection. Organization for Standardization, 2019.

[39] Státní zdravotní ústav. Povolení pro vyšetřování SARS-CoV-2. Dostupné z: http://www.szu.cz/ tema/prevence/povoleni-pro-vysetrovani-sars-cov-2)

[40] OČENÁŠKOVÁ, V. Komunální odpadní voda jako diagnostické médium. VTEl, 2018, roč. 60, č. 1, str. 28-30. ISSN 0322-8916.

[41] GRACIA-LOR, E, CASTIGLIONL, S, BADE, $R$, et al. Measuring biomarkers in wastewater as a new source of epidemiological information: Current state and future perspectives. Environment International, 2017, 99, p. 131-150. DOI: 10.1016/j.envint.2016.12.016. ISSN 0160-4120. Dostupné z: http:// linkinghub.elsevier.com/retrieve/pii/S0160412016306936

[42] HART, O.E. and HALDEN, R.U. Computational analysis of SARSCoV-2/COVID-19 surveillance by wastewater-based epidemiology locally and globally: Feasibility, economy, opportunities and challenges. Science of the Total Environment, 2020. Dostupné z: https://doi.org/10.1016/j.scitotenv.2020.

[43] Protocols.io. 2019-nCoV Wastewater Epidemiology. Dostupné z: https://www.protocols.io/ groups/2019ncov-wastewater-epidemiology.

[44] La verdad. Las depuradoras se convierten en centinelas del coronavirus. Dostupné z: https://www.laverdad.es/murcia/depuradoras-convierten-centinelas-20200412234209-ntvo. html\#vca=fixed-btn\&vso=rrss\&vmc=wh\&vli=Regi\%C3\%B3n-de-Murcia

[45] AHMED, W., ANGEL, N., EDSON, J., et al. First confirmed detection of SARS-CoV-2 in untreated wastewater in Australia: A proof of concept for the wastewater surveillance of COVID-19 in the community. Science of the Total Environment, 2020. Dostupné z: https://doi.org/10.1016/j. scitotenv.2020.138764

[46] Eurocommpr. Včasné varování: Rakousko testuje odpadní vody na koronavir. Dostupné z: https://www.eurocommpr.at/cz/Newsroom/Tiskove-zpravy/Vcasne-varovani-Rakousko-testuje-odpadni-vody-na-koronavir

[47] WU, F. et al. SARS-CoV-2 titers in wastewater are higher than expected from clinically confirmed cases. DOI: https://doi.org/10.1101/2020.04.05.20051540

[48] Eagri. Vybrané údaje majetkové evidence (VÚME) a Vybrané údaje provozní evidence (VúPE) za rok 2018. Dostupné z: http://eagri.cz/public/web/mze/voda/vodovody-a-kanalizace/vybraneudaje-z-majetkove-a-provozni-evidence-vodovodu-a-kanalizaci/vybrane-udaje-majetkoveevidence-vume-a.htm

[49] WHO. Coronavirus disease (COVID-19) Pandemic. Dostupné z: https://www.who.int/emergencies/ diseases/novel-coronavirus-2019

[50] Stanovisko Národního referenčního centra (NRC) pro pitnou vodu k otázce přenosu nového koronaviru (SARS-CoV-2) pitnou vodou. Dostupné z: http://szu.cz/uploads/documents/chzp/voda/ pdf/Stanovisko_NRC_coronaviry_a_pitna_voda.pdf

[51] Stanovisko národního referenčního centra pro hygienu půdy a odpadů k prevenci nákazy COVID - 19 u pracovníků provozů kanalizací a čistíren odpadních vod. Dostupné z: http://www.szu.cz/uploads/ Epidemiologie/Coronavirus/Odpady/Stanovisko_NRC_k_ochrane_pracovniku_kanalizaci_a_COV.pdf

\section{Autoři}

RNDr. Hana Mlejnková, Ph.D.'

凶hana.mlejnkova@vuv.cz

ORCID: 0000-0002-3892-6226

Ing. Věra Očenášková

凶vera.ocenaskova@vuv.cz

Mgr. Kateřina Sovová, Ph.D. ${ }^{2}$

凶katerina.sovova@vuv.cz

Mgr. Petra Vašíčková, Ph.D. ${ }^{3}$

凶vasickova@vri.cz

Ing. Eva Juranová

凶eva.juranova@vuv.cz

ORCID: 0000-0001-9021-7307

'Výzkumný ústav vodohospodářský T. G. Masaryka, v. v. i.

${ }^{2}$ Výzkumný ústav vodohospodářský T. G. Masaryka, v. v. i., pobočka Brno

${ }^{3}$ Výzkumný ústav veterinárního lékařství, v. v. i.

Přispěvek prošel lektorským řízením.

DOI: $10.46555 /$ VTEI.2020.04.005

\section{CORONAVIRUS SARS-COV-2 IN SURFACE AND WASTEWATER}

\section{MLEJNKOVA, H.'; OCENASKOVA, V.'; SOVOVA, K. ${ }^{2}$; VASICKOVA, P. ${ }^{3}$; JURANOVA, E. ${ }^{1}$}

${ }^{1}$ TGM Water Research Institute, p.r.i.

${ }^{2}$ TGM Water Research Institute, p.r.i., Brno Branch

${ }^{3}$ Research Institute of Veterinary Medicine, p.r.i.

Keywords: COVID 19 - SARS-CoV-2 - wastewater surface water - contamination - wastewater based epidemiology - early-warning tool - biomarker

The paper provides actual clear information about viruses and coronaviruses, including SARS-CoV-2, the possibility of contamination of surface water and wastewater by this virus. The RT-qPCR method of determination of SARS-CoV-2 in water is also described. The use of monitoring the presence of the virus in wastewater as biomarker to monitor its occurrence in the population and as an early-warning tool of a possible new wave of disease is also mentioned. 